Fayoum Journal of Agricultural Research
and Development
ISSN:1110- 7790

\title{
Weed interference and control in sugar beet (Beta vulgaris L.)
}

\author{
Nair Ibrahim Mahmoud Hassan Darwish ${ }^{1 *}$, Mohammed Ali Abdelkader Abd El- \\ Kader $^{1}$, Adel Mohamed AbdEl-Aal ${ }^{2}$ and Khalid Azzam AbdulRahman Azzam ${ }^{2}$ \\ ${ }^{1}$ Agronomy Department, Faculty of Agriculture, Al- Azhar University \\ ${ }^{2}$ Sugar Crops Res. Lnst., ARC.
}

\begin{abstract}
:
Two filed experiments were carried out at Tamya Agricultural Research Station, Agricultural Research Center, El-Fayoum Governorate (Middle Egypt) in both successive winter growing seasons of 2016/17 and 2017/18 to determine the effect of some weed control treatments on yield, yield components, quality of sugar beet (and its associated weeds. The randomized complete blocks design with four replications was used in these experiments. The major weed species associated sugar beet crop in field experiments in both seasons were Avena spp., Phalaris spp. as annual grassy weeds, Brassica nigra L., Chenopodium sp., Sonchus oleraceus L., Medicago polymorpha L., Melilotus indica L., Anagallus arvensis, Ammi majus L., Euphorbia helioscopia and Rumex dentatus L. as annual broad-leaved weeds. All weed control treatments statistically significant reduced dry weight of weeds $\left(\mathrm{g} / \mathrm{m}^{2}\right)$ in both seasons at 75 and 105 days after planting (DAP). Hand hoeing three times recorded the lowest value of dry weight of weeds in both seasons.
\end{abstract}

KEYWORDS: Weed, sugar beet, yield components, Avena spp., Phalaris spp.

Received: 3/11/ 2020

Accepted: 10/12/ 2020 


\section{INTRODUCTION:}

Sugar beet (Beta vulgaris L.) is considered as an important sugar crop in Egypt and it is considered the second crop after sugarcane for sugar production. It can be grown in northern regions of the country and in the new reclaimed area. Recently, the contribution of sugar beet to sugar production increased to reach about $48.1 \%$ of the total sugar production in 2019 season. Sugar beet is cultivated in Egypt 598 thousand fed. High yield and quality of sugar beet is the end product of many factors including weed control treatments.

Weed competition is considered one of the major obstacles in preventing the achievement of maximum sugar beet yield. Weeds not only compete with sugar beet for the necessary elements of growth such as light, water and nutrients, but also harbor insects and increase the incidence of diseases and harvest losses. Mirshekari et al. (2010), reported that the decreased root yield of sugar beet from $75 \mathrm{t} / \mathrm{ha}$ to $58 \mathrm{t} / \mathrm{ha}$ when 16 redroot pigweed $/ \mathrm{m}$ of row allowed to interfere for whole season, compared to weed free for whole season as well as increased sugar yield losses. Odero et al. (2010), found that the wild buckwheat had greater interference on sugar beet. It had a negative effect on root and sucrose yields of sugar beet this may be due to wild buckwheat strength competitive ability with sugar beet. The critical period of weed control under infestation by wild buckwheat was 32 and 48 days after sugar beet emergence DAE to avoid 5 and $10 \%$ root yield losses, respectively.

Chetin et al. (2008), showed that good control for Salvia reflexa in sugar beet with Betanal Expert OF [ethofumesate + desmedipham + phenmedipham] (1.7-2.1 1/ha.) + Caribo [triflusulfuron] (40-50 g/ha) + Lontrel Grand [clopyralid] (0-80 g/ha).

Deveikyte and Seibutis (2008), recorded that all herbicide treatments (phenmedipham + desmedipham + ethofumesate, metamitron and triflusulfuron-methyl) gave more consistent control of Chenopodium album L., Tripleurospermum perforatum (Merat), Polygonum aviculare L. and Thlaspi arvense L. in sugar beet. Olsson (2008), concluded that in sugar beet using the normal dose $(0.651 /$ ha. Goltix [metamitron], 1.0 Betanal [desmedipham]) gives the best weed control without significant reduction in sugar yield. Rapparini (2008), cleared that Betaren Extra [desmedipham + phenmedipham + ethofumesate] proved to be a very wide spectrum herbicide, highly effective against annual dicotyledonous weeds, giving 95.195.8\% control at doses of 3-4 liters/ha, a triple application $(1+1+1$ 1/ha. $)$ was particularly effective for weed control. Jursik and Holec (2009), stated that high efficacy on Euphorbia helioscopia can be reached by using herbicides with active ingredients quinmerac, triflusulfuron, and in early growth stages also desmedipham. Zargar et al. (2010), showed that times of mechanical control and 
herbicides have the most reduction on density and weeds biomass of (Chenopodium album and Amaranthusretroflexus) best results were achieved in mechanical control at 4-6 leaves stage or using herbicide was Goltix + Betanal progress. Abo ElHassan Rasha (2010), reported that weed control treatments significantly decreased the dry weight of weeds as compared with unweeded after 60 and 90 days from planting in both seasons. She added that decreasing the rate of Betanal Progress when applied twice at rate of (135 g a.i. / fed.) followed by Fusilade Super at (94.75 g a.i. / fed.) in tank mixed with vegetable oils showed good results on total annual weeds as compared to Betanal Progress when applied twice at rate of (135 g a.i. / fed.) followed by Fusilade Super to (94.75 g a.i./fed.) tank mixed with mineral oils in both seasons. Abo ElHassan Rasha (2010), found that root length, root diameter, root weight, top fresh weight, top yield, root yield, sucrose percentage, sugar yield of sugar beet plant had significantly affected by weed control treatments in both growing seasons, where as T.S.S. $\%$ and purity $\%$ did not significantly affect by weed control treatments.

\section{MATERIALS AND METHODS:}

Two filed experiments were carried out at Tamya Agricultural Research Station, Agricultural Research Center, El-Fayoum Governorate (Middle Egypt) in both successive winter growing seasons of $2016 / 17$ and $2017 / 18$ to determine the effect of some weed control treatments on yield, yield components, quality of sugar beet and its associated weeds.
Weed control treatments were used as follows:

1. Control (without any weed control treatment).

2. Acetochlor(2-chloro-N(ethoxymethyl)-N-(2-ethyl-6methylphenyl) acetamide known commercially as Harness $84 \%$ EC at the rate of $750 \mathrm{~cm}^{3} / \mathrm{fed}$. applied pre-planting.

3. Metamitron (4-amino- 4,5- dihydro -3- methyl -6-pheny 1-1,2,4- triazin5-one;4-amino-3-methyl-6-phenyl1,2,4-triazin-5(4H)-one) known commercially as Goltix $70 \%$ SC at the rate of $1.5 \mathrm{~L} /$ fad. applied post emergence (4 true leaves of sugar beet)

4. Harness $84 \% \mathrm{EC}$ at the rate of 750 $\mathrm{cm}^{3} /$ fed. applied pre-planting followed by Goltix 70\% SC at the rate of $1.5 \mathrm{~L} / \mathrm{fad}$. applied post emergence (4 true leaves of sugar beet)

5. Harness $84 \% \mathrm{EC}$ at the rate of 750 $\mathrm{cm}^{3} /$ fed. applied pre-planting followed by one hoeing after one month rom application

6. Goltix $70 \% \mathrm{SC}$ at the rate of $1.5 \mathrm{~L}$ /fad. applied post emergence (4 true leaves of sugar beet) followed by one hoeing after one month rom application

7. Hoeing three times at 4,8 and 12 weeks from sowing.

The randomized complete block design with four replicates was used in these experiments. Plot area was $10.5 \mathrm{~m}^{2}$ (1/400 fed.), include 5 rows and the row length was $3.5 \mathrm{~m}$ and wide $60 \mathrm{~cm}$ apart between the ridge.

Sugar beet cultivar "Kwamera" (Beta vulgaris L.) was sown on $15^{\text {th }}$ and $20^{\text {th }}$ of October in 2016/17 and $2017 / 18$, respectively, on one ridge in 
hill and $15 \mathrm{~cm}$ apart between the hills. Harvested on $14^{\text {st }}$ and 17 th of May in 2016/17 and 2017/18, respectively. The preceding summer crop was maize (Zea mays L.) in both seasons.

Phosphorus fertilizer was added at land preparation with the rate of $31 \mathrm{~kg} / \mathrm{fed} \mathrm{P}_{2} \mathrm{O}_{5}$ in the form of calcium super phosphate $(15.5 \%$ $\mathrm{P}_{2} \mathrm{O}_{5}$,) Nitrogen fertilizer was applied in the form of urea $(46.5 \% \mathrm{~N})$ at rate of $80 \mathrm{~kg} \mathrm{~N} / \mathrm{fed}$, in two equal portions, the first dose before the first irrigation and the second dose before the second irrigation. Potassium was added with first of nitrogen dose at the rate of 50 $\mathrm{kg} \mathrm{K} \mathrm{K}_{2} \mathrm{O} / \mathrm{fed}$ in the form of potassium sulfate $\left(48 \% \quad \mathrm{~K}_{2} \mathrm{O}\right.$, ) the other normal agricultural practices of sugar beet cultivation were done as recommended.

All herbicides treatments were sprayed with a knapsack sprayer equipped with one nozzle boom and the water volume was $200 \mathrm{~L} /$ fed.

\section{Data recorded:}

During the growing seasons, the following data were recorded:-

\section{Effect of weed control treatments on weeds:}

Weeds were hand pulled from one square meter chosen at random in each plot after 75 and 105 days After planting, identified and classified to annual broad and narrow leaved weeds to record the following traits:-

1- Dry weight of annual grassy weeds $\left(\mathrm{g} / \mathrm{m}^{2}\right)$.

2- Dry weight of annual broad-leaved weeds $\left(\mathrm{g} / \mathrm{m}^{2}\right)$.

3- Dry weight of total annual weeds $\left(\mathrm{g} / \mathrm{m}^{2}\right)$.

Weeds were air-dried and then were oven dried at $70^{\circ} \mathrm{C}$ for $48 \mathrm{hr}$, until a constant weight was reached.
Dry weight of weeds for each group $\left(\mathrm{g} / \mathrm{m}^{2}\right)$ was recorded.

All data were statistically analyzed according to technique of analysis of variance (ANOVA) for the randomized complete block design with four replications as mentioned by Gomez and Gomez (1984) by means of "SAS" computer software package Duncan multiple range test was used for compare among treatment means Duncan (1955).

\section{RESULTS AND DISCUSSION:}

\section{Effect of weed control treatments on weeds:}

The major weed species associated sugar beet crop in field experiments in both seasons were Avena spp., Phalaris spp. as aaqnnual grassy weeds, Brassica nigra L., Chenopodium sp., Sonchus oleraceus L., Medicago polymorpha L., Melilotus indica L., Anagallus arvensis, Ammi majus L., Euphorbia helioscopia and Rumex dentatus L. as annual broad-leaved weeds.

\section{1 - Dry weight of annual grassy weight $\left(\mathrm{g} / \mathrm{m}^{2}\right)$ :}

Results in Table (1) reported that all weed control treatments significantly reduced dry weight of annual grassy weeds $\left(\mathrm{g} / \mathrm{m}^{2}\right)$ in both seasons at 75 and 105 days after planting (DAP) than the control. Hand hoeing three times recorded the lowest value of dry weight of annual grassy weeds in both seasons and different surveys time (75 and 105 DAP), followed by Goltex plus one hoeing, Harnes plus one hoeing and Harnes followed by Goltex, however, the 
highest value of dry weight of annual grassy weeds were resulted from unweeded check plots.

Reduction percentage in annual grassy weeds at $75 \& 105$ DAP due to the using of hand hoeing thrice, Goltex plus one hoeing, Harnes plus one hoeing, Harnes followed by Goltex and Goltix as will as Harnes were 98.5, 95.2; 96.3, 93.6; 94.6, 94.1; 92.3, $92.1 ; 67.2,63.3$ and 46.3, 35, respectively, in the first season. Whereas, in the second season the reduction percentages were 97.2, 94.5; $96.3,93.5 ; 95.3,89.2 ; 67.9,63.3$ and 9.8 , 46., respectively, compared with unweeded check plots. Similar results recorded by Gabibullaev (1996), Gonik and Val'ko (1996), Tyla and Petroviene (1996), Deveikyte (1997b), Tezuka et al. (1997) and Deveikyte (2005).

Table. (1). Effect of weed control treatments on dry weight of annual grassy weeds $\left(\mathrm{g} / \mathrm{m}^{2}\right)$ at 75 and 105 days after planting in 2016/17 and 2017/18 winter seasons.

\begin{tabular}{ccccc}
\hline Treatments & $\begin{array}{c}75 \\
\text { DAP }\end{array}$ & $\begin{array}{c}\text { \% } \\
\text { control }\end{array}$ & $\begin{array}{c}105 \\
105 \mathrm{DAP}\end{array}$ & $\begin{array}{c}\text { \% } \\
\text { control }\end{array}$ \\
\hline Harness & \multicolumn{4}{c}{$2016 / 17$} \\
Goltix & $204.6 \mathrm{~b}$ & $\mathbf{4 6 . 3}$ & $459.2 \mathrm{~b}$ & $\mathbf{3 5 . 0}$ \\
Harness followed by Goltix & $125.0 \mathrm{c}$ & $\mathbf{6 7 . 2}$ & $259.3 \mathrm{c}$ & $\mathbf{6 3 . 3}$ \\
Harness + one hoeing & $29.4 \mathrm{~d}$ & $\mathbf{9 2 . 3}$ & $55.8 \mathrm{~d}$ & $\mathbf{9 2 . 1}$ \\
Goltix+ one hoeing & $20.6 \mathrm{~d}$ & $\mathbf{9 4 . 6}$ & $41.9 \mathrm{e}$ & $\mathbf{9 4 . 1}$ \\
Hoeing three times & $14.1 \mathrm{e}$ & $\mathbf{9 6 . 3}$ & $45.5 \mathrm{e}$ & $\mathbf{9 3 . 6}$ \\
Unweeded (control) & $5.7 \mathrm{f}$ & $\mathbf{9 8 . 5}$ & $33.9 \mathrm{f}$ & $\mathbf{9 5 . 2}$ \\
& $381.0 \mathrm{a}$ & $\mathbf{0 . 0}$ & $706.5 \mathrm{a}$ & $\mathbf{0 . 0}$ \\
Harness & $247.0 \mathrm{~b}$ & $\mathbf{3 5 . 2}$ & $459.2 \mathrm{~b}$ & $\mathbf{5 1 . 6}$ \\
Goltix & $157.9 \mathrm{c}$ & $\mathbf{5 8 . 6}$ & $259.3 \mathrm{c}$ & $\mathbf{7 2 . 7}$ \\
Harness followed by Goltix & $23.1 \mathrm{e}$ & $\mathbf{9 3 . 9}$ & $55.8 \mathrm{~d}$ & $\mathbf{9 4 . 1}$ \\
Harness + one hoeing & $33.5 \mathrm{~d}$ & $\mathbf{9 1 . 2}$ & $41.9 \mathrm{e}$ & $\mathbf{9 5 . 6}$ \\
Goltix+ one hoeing & $18.2 \mathrm{f}$ & $\mathbf{9 5 . 2}$ & $61.3 \mathrm{~d}$ & $\mathbf{9 3 . 5}$ \\
Hoeing three times & $5.7 \mathrm{~g}$ & $\mathbf{9 8 . 5}$ & $33.9 \mathrm{f}$ & $\mathbf{9 6 . 4}$ \\
Unweeded (control) & $381.0 \mathrm{a}$ & $\mathbf{0 . 0}$ & $949.5 \mathrm{a}$ & $\mathbf{0 . 0}$ \\
\hline
\end{tabular}

(1) DAP = Days After Planting 
2 - Dry weight of annual broadleaved weeds $\left(\mathrm{g} / \mathrm{m}^{2}\right)$ :

Results in Table (2) showed that the effect of weed control treatments on annual broad-leaved in sugar beet at 75 and 105 DAPS.

Results revealed that weed control treatments had a significant effect on dry weight of annual broadleaved weeds $\left(\mathrm{g} / \mathrm{m}^{2}\right)$ in both seasons at 75 and 105 DAP. In both seasons the lowest values of dry weight of annual broad-leaved weeds were obtained from hand hoeing thrice follow by Harness + one hoeing, Goltix+ one hoeing, Harness followed by Goltix,
Harness alone and Golrtix alone.

The highest weed control percentage at 75 DAP, $98.1 \& 97.2$ was resulted from hand hoeing thrice thrice follow by Harness + one hoeing, Goltix + one hoeing, Harness followed by Goltix, Harness alone and Golrtix alone compared with unweeded check. These results are in agreement with those obtained by Gamuev et al. (1994), Yukhin and Absatrov (1996), Bosak and Janos (1997), Rapparini (1997), Montemurro et al. (1998), Chetin et al. (2008) and Abo ElHassan, Rasha (2010).

Table. (2). Effect of weed control treatments on dry weight of annual broadleaved weeds $\left(\mathrm{g} / \mathrm{m}^{2}\right)$ at 75 and $105 \mathrm{DAP}$ in 2009/10 and 2010/11 winter seasons.

\begin{tabular}{|c|c|c|c|c|}
\hline \multirow[t]{2}{*}{ Treatments } & $\begin{array}{c}75 \\
\text { DAP }^{(1)}\end{array}$ & $\begin{array}{c}\% \\
\text { control }\end{array}$ & $\begin{array}{c}105 \\
\text { DAP }\end{array}$ & \multirow[t]{2}{*}{$\begin{array}{c}\% \\
\text { control }\end{array}$} \\
\hline & \multicolumn{3}{|c|}{ 2016/17 } & \\
\hline Harness & $269.3 \mathrm{c}$ & 61.2 & $670.7 \mathrm{c}$ & 58.6 \\
\hline Goltix & $387.3 \mathrm{~b}$ & 44.2 & $950.9 \mathrm{~b}$ & 41.3 \\
\hline Harness followed by Goltix & $261.6 \mathrm{c}$ & 62.3 & $526.5 \mathrm{~d}$ & 67.5 \\
\hline Harness + one hoeing & $111.7 \mathrm{e}$ & 83.9 & $320.8 \mathrm{f}$ & 80.2 \\
\hline Goltix+ one hoeing & $138.1 \mathrm{~d}$ & 80.1 & $383.9 \mathrm{e}$ & 76.3 \\
\hline Hoeing three times & $13.2 \mathrm{f}$ & 98.1 & $35.6 \mathrm{~g}$ & i97.8 \\
\hline \multirow[t]{2}{*}{ Unweeded (control) } & $694.0 \mathrm{a}$ & $\mathbf{0 . 0}$ & $1620.0 \mathrm{a}$ & 0.0 \\
\hline & \multicolumn{4}{|c|}{ 2017/18 } \\
\hline Harness & $216.1 \mathrm{~b}$ & 58.2 & $717.2 \mathrm{~b}$ & 44.6 \\
\hline Goltix & $271.4 \mathrm{~b}$ & 47.5 & $565.7 \mathrm{c}$ & 56.3 \\
\hline Harness followed by Goltix & $177.8 \mathrm{~d}$ & 65.6 & $287.4 \mathrm{~d}$ & 77.8 \\
\hline Harness + one hoeing & $96.2 \mathrm{c}$ & fg81.4 & $264.1 \mathrm{e}$ & 79.6 \\
\hline Goltix+ one hoeing & $111.2 \mathrm{c}$ & 78.5 & $402.6 \mathrm{f}$ & 68.9 \\
\hline Hoeing three times & $14.5 \mathrm{e}$ & 97.2 & $52.0 \mathrm{~g}$ & 96.0 \\
\hline Unweeded (control) & $517.0 \mathrm{a}$ & 0.0 & $1294.5 \mathrm{a}$ & 0.0 \\
\hline
\end{tabular}


3- Dry weight of total annual weeds $\left(\mathrm{g} / \mathrm{m}^{2}\right)$ :

Data in Table (3) showed that the effects of weed control treatments on total annual weeds.

Results clearly indicated that the dry weight of total annual weeds $\left(\mathrm{g} / \mathrm{m}^{2}\right)$ significantly affected weed control treatments in both seasons at 75 and 105 DAP.

Hand hoeing three times recorded the lowest values of dry weight of total annual weeds at different surveys time (75 and 105 DAP) in both seasons followed by Goltix+ one hoeing, Harnees + one hoeing and Harness + Goltix .

The highest reduction percentages in total annual weeds at 75 \& 105 DAP due to hand hoeing thrice follow by Harness + one hoeing, Goltix+ one hoeing, Harness followed by Goltix, Harness alone and Golrtix alone compared with unweeded check, respectively,

From the above results it could be concluded that adding one hoeing with Harness or Goltix as broad-leaved herbicides enhanced toxicity for total annual weeds, as will as, using two herbicides together which one for controlling annual broad-leaved and grass weeds and other for controlling annual broad-leaved weeds can be increasing effectiveness for control total annual weeds due to increased reduction in dry weight of annual broad-leaved weeds. These results are in agreement with the findings of Deveikyte (1996), Deveikyte (1997a), Ievlev et al. (1997), El-Zouky (1998), Tyr et al. (1999), Farzin and Hossein (2004) and Deveikyte (2005).

Sugar beet crop weak growth in the first stage and plants are weak to compete with weeds such as weed species which appear with the emergence of sugar beet Deveikyte and Seibutis (2006) and this requires the maintenance of the sugar beet crop free from weeds for at least four to six weeks after emergence as 55 - 60 days after sowing, so used one herbicide during the period of growing sugar beet did not enough for over come on weeds problems, so must be using two herbicides or herbicide with one or two hand hoeing for conducted high productivity. 
Table (3): Effect of weed control treatments on dry weight of total annual weeds $\left(\mathrm{g} / \mathrm{m}^{2}\right)$ at 75 and 105 days after planting in $2009 / 10$ and 2010/11 winter seasons

\begin{tabular}{ccccc}
\hline Treatments & $\begin{array}{c}75 \\
\text { DAP(1) }\end{array}$ & $\begin{array}{c}\text { \% } \\
\text { control }\end{array}$ & $\begin{array}{c}105 \\
\text { DAP }\end{array}$ & $\begin{array}{c}\text { \% } \\
\text { control }\end{array}$ \\
& \multicolumn{4}{c}{$2016 / 17$} \\
Harness & $591.8 \mathrm{~b}$ & $\mathbf{4 4 . 9}$ & $1410.1 \mathrm{~b}$ & $\mathbf{3 9 . 4}$ \\
Goltix & $394.2 \mathrm{c}$ & $\mathbf{6 3 . 3}$ & $785.8 \mathrm{c}$ & $\mathbf{6 6 . 2}$ \\
Harness followed by Goltix & $282.2 \mathrm{~d}$ & $\mathbf{7 3 . 7}$ & $726.5 \mathrm{~d}$ & $\mathbf{6 8 . 8}$ \\
Harness + one hoeing & $152.2 \mathrm{e}$ & $\mathbf{8 5 . 8}$ & $417.8 \mathrm{e}$ & $\mathbf{8 2 . 0}$ \\
Goltix+ one hoeing & $141.1 \mathrm{f}$ & $\mathbf{8 6 . 9}$ & $362.7 \mathrm{f}$ & $\mathbf{8 4 . 4}$ \\
Hoeing three times & $18.9 \mathrm{~g}$ & $\mathbf{9 8 . 2}$ & $81.1 \mathrm{~g}$ & $\mathbf{9 6 . 5}$ \\
Unweeded (control) & $1075.0 \mathrm{a}$ & $\mathbf{0 . 0}$ & $2326.5 \mathrm{a}$ & $\mathbf{0 . 0}$ \\
& & $2017 / 18$ & \\
Harness & $518.4 \mathrm{~b}$ & $\mathbf{4 8 . 6}$ & $1229.9 \mathrm{~b}$ & $\mathbf{4 5 . 2}$ \\
Goltix & $335.8 \mathrm{c}$ & $\mathbf{6 6 . 7}$ & $751.1 \mathrm{c}$ & $\mathbf{6 6 . 5}$ \\
Harness followed by Goltix & $239.2 \mathrm{~d}$ & $\mathbf{7 6 . 3}$ & $668.2 \mathrm{~d}$ & $\mathbf{7 0 . 2}$ \\
Harness + one hoeing & $144.6 \mathrm{e}$ & $\mathbf{8 4 . 7}$ & $349.5 \mathrm{e}$ & $\mathbf{8 4 . 4}$ \\
Goltix+ one hoeing & $114.4 \mathrm{f}$ & $\mathbf{8 8 . 7}$ & $339.2 \mathrm{e}$ & $\mathbf{8 4 . 9}$ \\
Hoeing three times & $28.3 \mathrm{~g}$ & $\mathbf{9 7 . 2}$ & $113.3 \mathrm{f}$ & $\mathbf{9 5 . 0}$ \\
Unweeded (control) & $1009.0 \mathrm{a}$ & $\mathbf{0 . 0}$ & $2244.0 \mathrm{a}$ & $\mathbf{0 . 0}$ \\
\hline
\end{tabular}

\section{REFERENCES:}

Bosak, P. and M. Janos (1997): A weed control experiment in sugar beet Novenyvedelem, 33 (12): 623627

Chetin, A.D.; A.A. Borodin and L.E. Chmeleva (2008): Lanceleaf sage and other problem weeds in sugar beet crops. Sakharnaya Svekla. (6): 26-27.

Deveikyte, I. (1996): Possibilities for post-emergence sugar beet spraying. Lietuvos Zemdirbystes Instituto Mokslo Darbai, Zemdirbyste, (56): 91-100.

Deveikyte, I. (1997a): Effectiveness of herbicides in sugar beet stands. Integrated plant protection: achievements and problems. Proceedings of the scientific conference devoted to the 70th anniversary of plant protection science in Lithuania, DotnuvaAkademija, Lithuania, 7-9 September. 188-191.

Deveikyte, I. (1997b): Efficiency of various herbicides in sugar beets. Lietuvos Zemdirbystes Instituto Mokslo Darbai, Zemdirbyste, (57): 180-188.

Deveikyte, I. (2005): Sensitivity of Tripleurospermum perforatum and Chenopodium album on low rates of phenmedipham, desmedipham, etofumesate, metamitron and chloridazon. Lucrari Stiintifice, Universitatea de Stiinte Agricole Si Medicina Veter "Ion Ionescu de la Brad" Iasi, Seria Agron, Romania, 
(48): 386-392.

Deveikyte, I. and V. Seibutis (2008):

The influence of post-emergence herbicides combinations on broadleaved weeds in sugar beet. Zemdirbyste (Agric), 95 (3): 43-49.

Duncan, B.O. (1955): Multiple range and multiple range $\mathrm{F}$ test. Biometrics, (11): 1-42.

El-Zouky, I. (1998): Weed control strategies in sugar beet on the Bekaa plain. Comptes-rendus 6eme symposium Mediterraneen EWRS, Montpellier, France, 13-15 Mai, 291-298

Farzin, A. and G. Hossein (2004): Effect of separate and combined applications of herbicides on weed control and yield of sugar beet. Weed Tech., 18: (4) 968-976.

Gabibullaev, E.I. (1996): Results of work at the Kuban Demonstration Centre. Sakharnaya Svekla, (12): 21-22.

Gamuev, V.V.; V. Vilkov and G. Repina (1994): Sugar beet protection based on a Betanal system. Sakharnaya Svekla, (3): 2123.

Gomez, K.A. and A.A. Gomez (1984): Statistical procedure for agricultural research. $2^{\text {nd }}$ ed, John Wiley and sons, New York USA.

Gonik, G.E. and A.P. Val'ko (1996): How to increase the effectiveness of Centurion. Sakharnaya Svekla, (1): 8-9.

Ievlev, D.M.; N.K. Shapovalov; V.G. Babich and R.I. Shestakov (1997): Split application of herbicides. Sakharnaya Svekla, (4): 11-13

Jursik, M. and J. Holec (2009): Biology and control of another important weeds of the Czech
Republic: sun spurge - Euphorbia helioscopia L. Listy Cukrovarnicke a Reparske, 125(12): 342-346.

Mirshekari, B.; F. Farahvash and A.H.H.Z. Moghbeli (2010): Efficiency of empirical competition models for simulation of sugar beet (Beta vulgaris L.) yield at interference with redroot pigweed (Amaranthus retroflexus L.). Proc. of $3^{\text {rd }}$ Iranian Weed Science Congress, Volume 1: Weed biology and ecophysiology, Babolsar, Iran, 17-18 February, 581-58

Montemurro, P.; M. Fracchiolla and C. Lasorella (1998): Further results on post-emergence chemical weed control in sugar beet (Beta vulgaris 'saccharifera') in autumn sowing. Atti, Giornate fitopatologiche, Scicli e Ragusa, 3-7 maggio, 393398.

Odero, D.C.; A.O. Mesbah; S.D. iller and A.R. Kniss (2010): Wild buckwheat (Polygonum convolvulus) interference in sugar beet. Weed Tech., 24 (1): 59-63.

Olsson, R. (2008): does our weed control cost us sugar? Betodlaren, (2): 44-47.

Rapparini, G. (1997): Postemergence treatments in sugar beet. Informatore Agrario, 53 (10): 8191.

Rapparini, G. (2008): New Betarens in the system of post-emergence weed control. Sakha, (8): 18-20

Rasha, G.M. Abo El-Hassan (2010) Improving the efficiency of some herbicides in weed control in sugar beet by some adjuvants. M.Sc. Thesis, Fac. Agric. Cairo Univ., Egypt.

Tezuka, M.; T. Kajiyama; T. Arita; Y. Yoshimura; H. Ochi and M. 
Onami (1997): Herbicide spraying system on hill seeding sugar beet. Bulletin of Hokkaido Prefect Agric Experi St, (73): 81-84.

Tyla, G. and I. Petroviene (1996): The efficiency of Fusilade Super, $\mathrm{Nabu}$, Targa and Zellek for couch grass removal from fodder beet fields. Lietuvos Zemdirbystes Instituto Mokslo Darbai, Zemdirbyste, (56):83-89.

Tyr, S.; R. Pospisil; J. Novak; K. Cernusko and M. LackoBartosova (1999): Potential of chemical weed control in sugar beet. Listy Cukrovarnicke a Reparske, 115 (4): 116-118.

Yukhin, I.P. and K.H.S. Absatrov (1996): Separate post-emergence application of herbicides. Sakharnaya Svekla, (3):21-22

Zargar, M.; H. Najafi; E. Zand and F. Mighani (2010): Study of integrated methods for management of red-root pigweed and lambsquarters in single- vs. twin-row sugar beet. Proceedings of $3^{\text {rd }}$ Iranian Weed Science Congress

\section{تداخل الأعشاب الضارة ومكافحتها في بنجر السكرد)Beta vulgaris)}

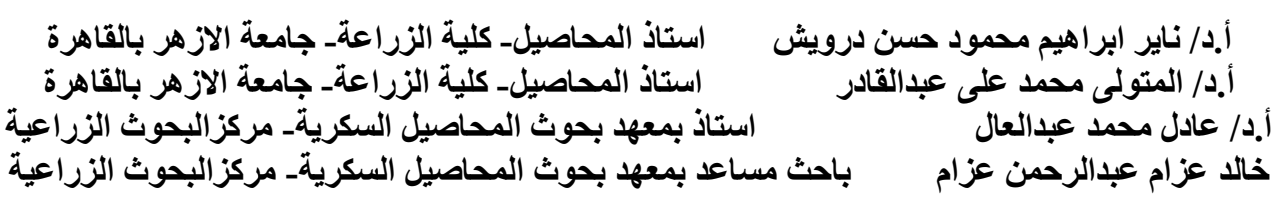

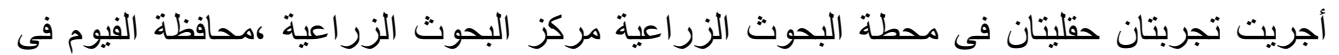

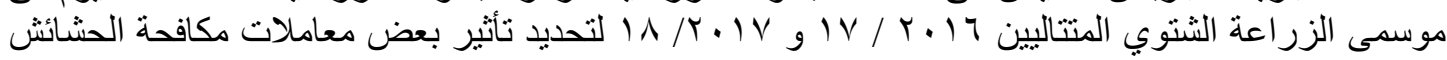

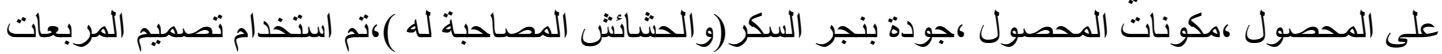

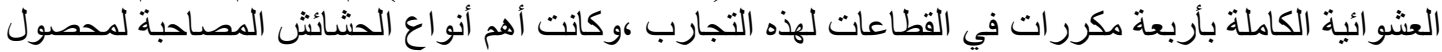

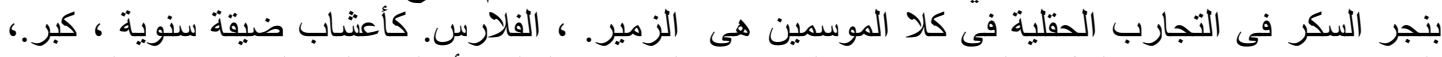

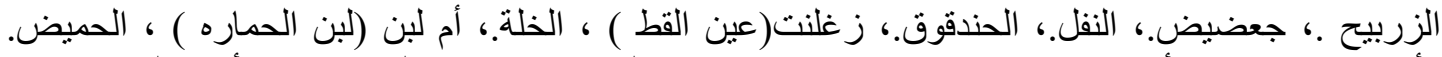

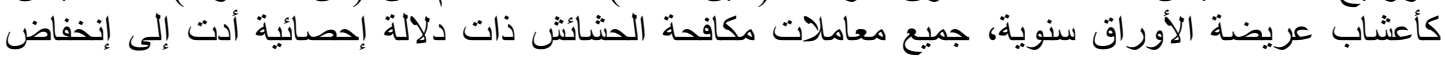

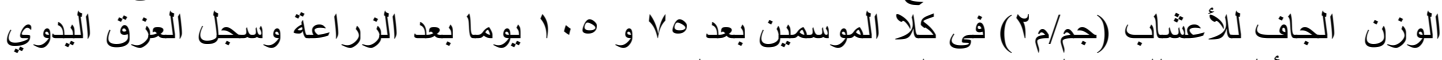
ثلاث مرات أقل قيمة للوزن الجاف من الحثائش فى كلا كلا الموسمين . 